\title{
Rigor, relevance and open-mindedness: the strategy of the journal of management control
}

\author{
Thomas W. Guenther ${ }^{1}$
}

(C) Springer-Verlag Berlin Heidelberg 2017

"Your assumptions are your windows on the world. Scrub them off every once in a while, or the light won't come in."

Isaac Asimov, American writer and professor of biochemistry at Boston University, USA

Both young researcher on their career path in academy and senior researchers, who are looking on recent trends in their field of research, are sometimes concerned about the narrow-mindedness of publication outlets. "Such research will never be published in our journal" or "We do not accept publication using method $\mathrm{x}$ " or "This theory is out" can be found in editor letters and on web sites of highly reputational journals nowadays.

The initial quote of Isaac Asimov categorizes these developments as assumptions limitating our view on the world, for most of us in matters of science, how we regard our object of analysis, firms and organizations. Following Asimov we can answer, let the light come in and enlighten what we see and find new things which carries us forward. I regret that it is sometimes difficult to discuss with the colleague next door from the management or marketing area because they have different journals, different preferred methods, different writing styles, and different ways to analyze and to communicate. Young researchers are pressed by the qualification and tenure systems to adapt to this unwritten laws of each community to get papers published and finally to make their living.

\footnotetext{
Thomas W. Guenther

thomas.guenther@tu-dresden.de

1 Technische Universität Dresden, 01062 Dresden, Germany
} 
Maybe I am too long in this business or too safe on my chair, but I doubt whether this is what changes the world, what helps organizations to better conduct their business and finally to create value and more wisdom for all of us.

Why don't we change? Indeed it is risky to present at a conference, which is not your major playground, to publish in journals you never published in or submitted for and to talk to colleagues outside your research field. Nevertheless, it may be very fruitful and interesting, you get new insights and you are challenged by other views on our world.

The Journal of Management Control being focused on management accounting and management control research wants to be open for different, diverse, and maybe challenging methods and research areas, for innovative views on management control, for different perspectives and approaches also on so far underresearched subjects. We more than welcome contributions that follow this mission. Nevertheless, contributions have to be rigorous and also should be relevant not only for research, but also for practice.

We offer scholars a fast turnover with 67 days on average to first decision and an average of 275 days to final acceptance. Acceptance rate in 2016 was $43 \%$. We are available at more than 8000 institutions around the world and downloads of papers increased by $16 \%$ per year over the last three years reaching now more than 40,000 per year. Our SCImago Journal Rank increased strongly from 0.135 in 2013 to 0.605 in 2015 and our Source Normalized Impact per Paper (SNIP) developed from 0.387 to 0.957 over the same time span. We are proud of this development and hope to further develop our journal.

To support this mission of the Journal of Management Control, we are happy to further expand our team of editors, after Sally K. Widener and Frank Verbeeten, by Josep Bisbe from ESADA Business School in Barcelona, Spain. Josep Bisbe has published in highly ranked journals, such as European Accounting Review, Management Accounting Research, Long Range Planning, Accounting, Organizations and Society and Accounting and Business Research.

In 2016, the following reviewers in alphabetical order gave us their honour, dedicated their precious time for our papers and supported us with their expertise and judgement. We are unbelievable thankful for this great resource of reviewers of the Journal of Management Control (reviews finished in 2016).

\begin{tabular}{llll}
\hline Title & Last name & First name & Affiliation \\
\hline Dr. & Bedford & David & University of Technology Sydney, Australia \\
Prof. Dr. & Bassen & Alexander & University of Hamburg, Germany \\
Prof. Dr. & Berens & Wolfgang & Münster University, Germany \\
Prof. & Bisbe Vinas & Josep & ESADE Business School, Barcelona, Spain \\
Prof. & Bjornenak & Trond & NHH Norwegian School of Economics, Bergen, \\
& & & Norway \\
Dr. & Brauneis & Alexander & University of Klagenfurt, Austria \\
Prof. & Brown & David A. & University of Technology Sydney, Australia \\
Prof. Dr. & Crasselt & Nils & Bergische Universität Wuppertal, Germany \\
Dr. & Enberg & Cecilia & Linköping University, Sweden \\
Dr. & Endrikat & Jan & Technische Universität Dresden, Germany \\
\hline
\end{tabular}




\begin{tabular}{|c|c|c|c|}
\hline Title & Last name & First name & Affiliation \\
\hline Dr. & Fourné & Sebastian & $\begin{array}{l}\text { WHU Otto Beisheim School of Management, } \\
\text { Vallendar, Germany }\end{array}$ \\
\hline Dr. & Franco-Santos & Monica & Cranfield University, United Kingdom \\
\hline Prof. Dr. & Fried & Andrea & Linköping University, Sweden \\
\hline Dr. & Friestad & Liv Bente & University of Agder, Norway \\
\hline Prof. Dr. & Gleich & Ronald & European Business School University, Germany \\
\hline Prof. Dr. & Goetze & Uwe & Technische Universität Chemnitz, Germany \\
\hline Prof. Dr. & Guenther & Thomas & Technische Universität Dresden, Germany \\
\hline Prof. Dr. & Haller & Axel & Universität Regensburg, Germany \\
\hline Dr. & Haustein & Ellen & University of Rostock, Germany \\
\hline Prof. Dr. & Hess & Thomas & Ludwig-Maximilian University Munich, Germany \\
\hline Prof. Dr. & Hiebl & Martin & University of Siegen, Germany \\
\hline Prof. Dr. & Himme & Alexander & Kuehne Logistics University, Germany \\
\hline Prof. Dr. & Hirsch & Bernhard & Universität der Bundeswehr München, Germany \\
\hline Dr. & Hummel & Katrin & Universitat Zurich, Switzerland \\
\hline Prof. & Järvenpää & Marko & University of Jyväskylä, Finland \\
\hline Prof. & Kajiwara & Takehisa & Kobe University, Japan \\
\hline Prof. Dr. & Kajüter & Peter & WWU Münster, Germany \\
\hline Prof. & Kihn & Lili-Anne & University of Tampere, Finland \\
\hline Prof. Dr. & Knauer & Thorsten & Ruhr University of Bochum, Germany \\
\hline Dr. & Kruis & Anne-Marie & Nyenrode Business Universiteit, The Netherlands \\
\hline Prof. Dr. & Kunz & Jennifer & Universitaet Augsburg, Germany \\
\hline Prof. Dr. & Letmathe & Peter & RWTH Aachen University, Germany \\
\hline Prof. Dr. & Linder & Stefan & ESSEC Business School, Paris, France \\
\hline Dr. & Linnenluecke & Martina & University of Queensland, Australia \\
\hline Prof. Dr. & Lueg & Rainer & Aarhus University, Danmark \\
\hline Prof. & Lukka & Kari & University of Turku, Finland \\
\hline Prof. & Madini & Paola Maria & University of Kent, United Kingdom \\
\hline Dr. & Malagueno & Ricardo & University of East Anglia, United Kingdom \\
\hline Prof. Dr. & Möller & Klaus & Universitaet St. Gallen, Switzerland \\
\hline Prof. Dr. & Obermaier & Robert & Universitat Passau, Germany \\
\hline Jun-Prof. Dr. & Ott & Christian & Europa-Universität Viadrina, Germany \\
\hline Prof. & Pellinen & Jukka & $\begin{array}{l}\text { University of Jyväskylä, School of Business and } \\
\text { Economics, Finland }\end{array}$ \\
\hline Prof. Dr. & Reimer & Marko & $\begin{array}{l}\text { WHU Otto Beisheim School of Management, } \\
\text { Vallendar, Germany }\end{array}$ \\
\hline Prof. Dr. & Rohlfing-Bastian & Anna & Goethe-Universität Frankfurt am Main \\
\hline Prof. Dr. & Schaeffer & Utz & $\begin{array}{l}\text { WHU Otto Beisheim School of Management, } \\
\text { Vallendar, Germany }\end{array}$ \\
\hline Prof. Dr. & Schöndube & Jens Robert & Leibniz Universitat Hannover, Germany \\
\hline Prof. Dr. & Sommer & Friedrich & University of Bayreuth, Germany \\
\hline Prof. Dr. & Souren & Rainer & Technische Universitaet Ilmenau, Germany \\
\hline Prof. Dr. & Speckbacher & Gerhard & Wirtschaftsuniversitat Wien, Austria \\
\hline Prof. Dr. & Strauss & Erik & Universitaet Witten/Herdecke, Germany \\
\hline Prof. & Umans & Timurs & Kristianstad University, Sweden \\
\hline Prof. Dr. & Verbeeten & Frank & Utrecht University, The Netherlands \\
\hline Prof. Dr. & Wald & Andreas & University of Agder, Norway \\
\hline Prof. Dr. & Weissenberger & Barbara & Heinrich-Heine University Düsseldorf, Germany \\
\hline
\end{tabular}

The articles included in this second issue of 2017 represent the wide horizon of our journal covering the broad perspective of management control research nowadays. The unique selling proposition of our journal is to give floor to diverse views on management accounting and control not limited to certain mainstreams and to open 
a wide space for researchers to present different methods, different fields of research and different perspectives within the core of management control.

Partial Least Squares (PLS) as a variance-based structural equation modelling method has been heavily discussed, critized and even stigmatised in the literature. Christian Nitzl and Wynne W. Chin explain in a methodological paper how PLS can be used and is used by management accounting researchers. They show that the properties of PLS go far beyond an instrument for "smaller" sample sizes and not fulfilled normal distribution assumptions by demonstrating the properties of PLS and by presenting three unique, so far seldomly used features of PLS.

Daniela Ruggeri and Carmela Rizza explore drawing on actor network theory the role of accounting information system (AIS) innovation in selecting suppliers. More specifically, they interpret the introduction of accounting information system as a process of translation where AIS is not just an accounting tool which explains reality, but is a boundary object which enables allies among actors helping them to show their own interests and to solve controversies. Their paper is based on a longitudinal case study in the Italian manufacturing sector.

Since the 1980s, research on new product development (NPD) has steadily increased. However, due to the fragmented character of the research field, there is still ambiguity how successful NPD projects look like. A holistic framework covering promising practices is missing. Drawing on a body of 284 publications, Benedikt Müller-Stewens and Klaus Möller develop a framework with nine clusters to derive potential explanations for product success. Thus, they are able to inform future researchers on a landmap of explored success drivers and they derive trends and paths for future research.

Last but not least, Björn Christensen and Alexander Himme demonstrate in a quantitative case study how statistics can be used to further develop environmental management accounting to better measure energy consumption. The authors suggest a statistical approach that can be used in order to measure energy utilization easily and cost-efficiently, which in turn provides information input to improve environmental management accounting (e.g., cost allocations). The approach is demonstrated in a case study of a firm from an energy-intensive industry.

Dresden, May 2016

For the team of editors

Prof. Dr. Thomas W. Günther

Managing editor 